\title{
Mutations in $\beta$-Catenin and APC Genes are Uncommon in Esophageal and Esophagogastric Junction Adenocarcinomas
}

\author{
Young W. Choi, M.D., Elisabeth I. Heath, M.D., Richard Heitmiller, M.D., Arlene A. Forastiere, M.D., \\ Tsung-Teh Wu, M.D., Ph.D. \\ Division of GI/Liver Pathology, Department of Pathology (YWC, T-TW), Medical Oncology, Oncology \\ Center (EIH, AF), and Division of Thoracic Surgery, Department of Surgery (RH); The Johns Hopkins \\ University School of Medicine, Baltimore, Maryland
}

$\beta$-catenin plays important roles in both intercellular adhesion and signal transduction. Mutations in the $\beta$-catenin or adenomatous polyposis coli (APC) gene can alter the degradation of $\beta$-catenin and cause aberrant accumulation of $\beta$-catenin result in increased transcription of target genes. The dysregulated $\mathrm{APC} / \boldsymbol{\beta}$-catenin pathway has been recently discovered as an important mechanism of tumorigenesis in various cancers, but its role in esophageal adenocarcinomas is not clear. Therefore, we studied the $\beta$-catenin gene mutation, allelic loss of chromosome 5q, and $A P C$ gene mutation in esophageal and esophagogastric junction adenocarcinomas. Two (2\%) somatic mutations in exon 3 of the $\beta$-catenin gene, encompassing the region for glycogen synthase kinase-3 $\beta$ phosphorylation, were detected from 109 adenocarcinomas. Chromosomal allelic loss on $5 q$ was frequent in $\mathbf{4 5 . 3 \%}(\mathbf{4 4 / 9 7 )}$ of tumors. Only one missense mutation in the mutation cluster region of the $A P C$ gene was detected from 38 esophageal and esophagogastric junction adenocarcinomas with the $5 q$ allelic loss. Our results based on partial screening mutational analyses indicate that mutations of APC/ $\beta$-catenin pathway, unlike in colorectal carcinoma, involve only a small subset of esophageal and esophagogastric junction adenocarcinoma.

KEY WORDS: APC, $\beta$-Catenin, Esophageal adenocarcinoma, Mutation.

Mod Pathol 2000;13(10):1055-1059

Copyright () 2000 by The United States and Canadian Academy of Pathology, Inc.

VOL. 13, NO. 10, P. 1055, 2000 Printed in the U.S.A.

Date of acceptance: April 17, 2000.

Address reprint requests to: Tsung-Teh Wu, M.D., Ph.D., Division of Gastrointestinal/Liver Pathology, Department of Pathology, Ross Research Building, Room 632, The Johns Hopkins University School of Medicine, 720 Rutland Avenue, Baltimore, Maryland 21205-2196; e-mail: ttwu@welch.jhu.edu; fax 410-614-0671.
The incidence of esophageal adenocarcinoma in Western countries has been rapidly increasing (1-2). Barrett esophagus developing as a complication in approximately $10 \%$ to $12 \%$ of patients with chronic gastroesophageal reflux is the predisposing condition for developing esophageal adenocarcinoma (3-8). These patients have a greater than 100-fold higher risk than the general population of developing adenocarcinoma of the esophagus (8-9).

Esophageal adenocarcinoma can develop in Barrett esophagus through a multistep process in which the metaplastic epithelium progresses to dysplasia and eventually to adenocarcinoma $(8,10-$ 11). Studies of genetic abnormalities in esophageal adenocarcinoma and its precursor lesion have revealed alterations in p53 tumor suppressor gene and frequent allelic losses of chromosomal arms containing known tumor suppressor genes such as 17p (p53 gene), 18q (DCC, DPC4, and JV18-1), 5q (APC), and 9p (p16) (12-18). However, the molecular pathogenesis of esophageal cancers has not been completely elucidated.

$\beta$-catenin is a ubiquitous intracellular protein that plays an important role in the APC/ $\beta$-catenin/ Tcf pathway (19-20). The APC protein can complex with glycogen synthase kinase $3 \beta$ (GSK- $3 \beta$ ) to control degradation of $\beta$-catenin by phosphorylation of serine and threonine in the $\mathrm{NH} 2$ terminus of $\beta$-catenin (21-24). Mutations in the $A P C$ gene or $\beta$-catenin gene, especially in the GSK- $3 \beta$ phosphorylation region, can cause nuclear accumulation of $\beta$-catenin (25-26), as well as interact with the transcription factor (Tcf/Lef family) to activate target genes (19-20). This interaction contributes to loss of cell growth control and promotes tumorigenesis in colorectal carcinomas and other tumors (27-29). Mutation of the APC tumor suppressor gene has only rarely been reported in esophageal adenocarcinoma despite frequent chromosomal loss in $5 \mathrm{q}$ and abnormal $\beta$-catenin expression has been re- 
ported in esophageal adenocarcinoma (30-33), but their importance to the neoplastic process remains unclear. Therefore, we examined APC and $\beta$-catenin mutations and studied their roles in tumorigenesis of esophageal adenocarcinoma.

\section{MATERIALS AND METHODS}

\section{Specimens}

A total of 109 esophageal and esophagogastric junction (EGJ) adenocarcinomas (103 primary tumors and six xenograft tumors) from patients receiving esophagectomy identified from the surgical pathology files of The Johns Hopkins Hospital from 1988 to 1998 were included in this study. Among the 109 adenocarcinomas, $13(12 \%)$ were stage I, 35 (32\%) were stage II, 46 (43\%) were stage III, and 14 (13\%) were stage IV. Seventy-three $(67 \%)$ tumors were moderately differentiated, 35 (32\%) were poorly differentiated, and 1 (1\%) was well differentiated - all adenocarcinomas. Barrett mucosa was identified in $51 \%(55 / 109)$ of the tumors.

\section{DNA Extraction}

Primary adenocarcinoma and paired normal mucosa were microdissected from hematoxylin and eosin (H\&E)-stained slides using either a razor blade or tuberculin needle directly under a microscope for DNA extraction. Genomic DNA was extracted as described by Moskaluk et al. (34). For xenograft tumors and paired frozen normal esophageal mucosa, genomic DNA was extracted using Dneasy tissue kit (QIAGEN, Valencia, CA).

\section{Mutational Analyses of the $\beta$-Catenin Gene}

Genomic DNA from each tumor sample was amplified using the following primer pairs: 5'-ATGGAACCAGACAGAGGGGC-3' and 5'-GCTACTTGTTCTGAGTGAAG-3'. These amplified a 200-bp fragment of exon 3 of the $\beta$-catenin encompassing the region for GSK-3 $\beta$ phosphorylation site. Polymerase chain reaction (PCR) was performed under standard conditions in a $50-\mu \mathrm{L}$ volume using PCR Master (Boehringer Mannheim, Mannheim, Germany) and $1 \mu \mathrm{M}$ of both $5^{\prime}$ and $3^{\prime}$ oligonucleotides with 40 cycles $\left(94^{\circ} \mathrm{C}\right.$ for $1 \mathrm{~min}, 58^{\circ} \mathrm{C}$ for $1 \mathrm{~min}$, and $72^{\circ} \mathrm{C}$ for $2 \mathrm{~min}$ ). PCR products were purified using shrimp alkaline phosphatase and exonuclease I (USB Corporation, Cleveland, Ohio) and sequenced directly with internal primers (5'-AAAGCGGCTGTTAGTCACTFF-3' and 5'-GACTTGGGAGGTATCCACATCC-3') using SequiTherm EXCEL ${ }^{\mathrm{TM}}$ II DNA Sequencing Kit (Epicentre, Madison, WI). The oligonucleotides used for sequencing were end-labeled with $\left(\gamma^{-}{ }^{32} \mathrm{P}\right)$-ATP (NEN DuPont, Boston, MA) using T4 polynucleotide kinase. Each mutation was verified in both the sense and antisense directions. To detect deletion mutations in exon 3, PCR amplification was performed using the following primer pair (5'-CCAGCGTGGACAATGGCTAC-3' and 5'-TGAGCTCGAGTCATTGCATAC-3' corresponding to parts of the DNA sequence of exons 2 and 4, respectively) (28) on genomic DNA extracted from 24 frozen primary tumors and six xenograft tumors.

\section{Allelic Loss on Chromosome $5 q$}

Loss of heterozygosity ( $\mathrm{LOH}$ ) on the long arm of chromosome 5 (5q) was assessed by microsatellite assays using PCR amplification of three microsatellite markers (D5S299, D5S346, and D5S82) as described previously (11). Allelic loss of a marker was considered to be present when the microsatellite demonstrated absence or at least $50 \%$ decrease in intensity of a heterozygous band from the tumor as compared to the control esophageal mucosa. Loss of $5 q$ was considered positive when at least one of the three microsatellite markers showed loss. The results of allelic loss on $5 q$ for 79 adenocarcinomas from paraffin embedded tissue were published previously (11).

\section{Mutational Analysis of APC Gene}

Four sets of oligonucleotide primers (A1: $5^{\prime}-$ CAGACTTATTGTGTAGAAGA-3' and A2: 5' -CTCCTGAAGAAAATTCAACA-3' for codons 1260 to 1359; B1: 5'-AGGGTTCTAGTTTATCTTCA-3' and B2: 5' TCTGCTTGGTGGCATGGTTT-3' for codons 1339 to 1436; C1: 5'-GGCATTATAAGCCCCAGTGA-3' and C2: 5'-AAATGGCTCATCGAGGCTCA-3' for codons 1417 to 1516; D1: 5'-ACTCCAGATGGATTTTCTTG-3' and D2: 5'-GGCTGGCTTTTTTGCTTTAC-3' for codons 1497 to 1596) were used to amplify the mutation cluster region of the APC gene for primary tumors showing $\mathrm{LOH}$ or the $\mathrm{LOH}$ status was undetermined on chromosome $5 \mathrm{q}$ and all six xenograft tumors (35). Genomic DNA was amplified by PCR reactions with appropriate annealing temperature for each primer set and the conditions used for $\beta$-catenin gene amplification. The PCR products were sequenced directly with the same primers used for genomic DNA amplification.

\section{RESULTS}

\section{Mutations in the Exon 3 of the $\beta$-Catenin Gene}

Two of $109(2 \%)$ primary and xenograft esophageal and EGJ adenocarcinomas had mutations in exon 3 of the $\beta$-catenin gene. Both tumors had a missense mutation (TCT $\rightarrow$ TTT) at codon 37 , replacing serine to phenylanine at the GSK- $3 \beta$ phosphorylation site (Fig. 1). One of the two adenocarcinomas with $\beta$-catenin gene mutation arose in a background of Barrett esophagus with low-grade columnar epithelial dysplasia. No mutations in the 


\section{$\beta$-Catenin}

LGD

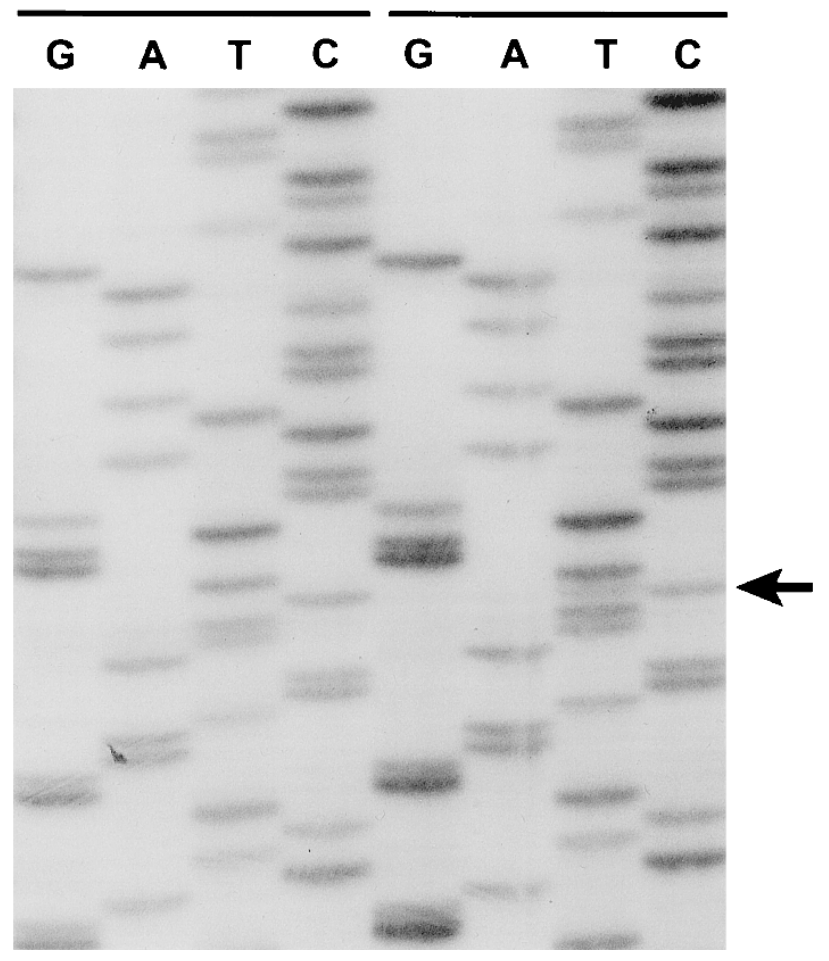

FIGURE 1. $\beta$-catenin gene mutation present in adenocarcinoma (Ca), but not in the Barrett mucosa with low grade columnar epithelial dysplasia (LGD). The mutation (arrow) was a missense mutation (C $\rightarrow$ T) at codon 37 changing a serine (TCT) to a phenylanine (TTT) at the GSK- $3 \beta$ phosphorylation site.

$\beta$-catenin gene were identified in nondysplastic or dysplastic Barrett mucosa from the same patient (Fig. 1). There was no deletion mutation in exon 3 of $\beta$-catenin gene in 30 (24 primary tumors and six xenograft tumors) esophageal and EGJ adenocarcinomas.

\section{Allelic Loss on Chromosome $5 q$ and Mutation of the APC Gene}

Allelic loss on chromosome $5 q$ was identified in $45.3 \%$ (44 out of 97) of the adenocarcinomas (Fig. 2A). In six adenocarcinomas, the status of allelic loss could not be determined (three showed microsatellite instability and three were homozygous for all three microsatellite markers).

There were no nonsense mutation but one $(2.6 \%)$ missense mutation (AGT $\rightarrow$ AAT, Ser to Asn) in codon 1398 of the APC gene was detected in 38 adenocarcinomas with allelic loss on $5 \mathrm{q}$ (Fig. 2B). No mutation was identified in six xenograft tumors and five adenocarcinomas with indeterminate $\mathrm{LOH}$ status on $5 \mathrm{q}$.
A

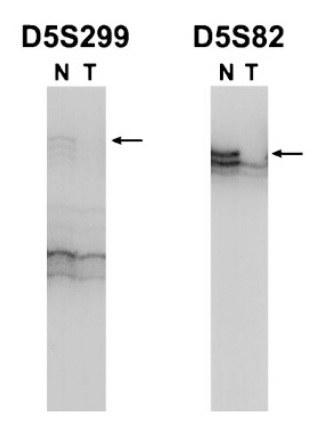

B APC

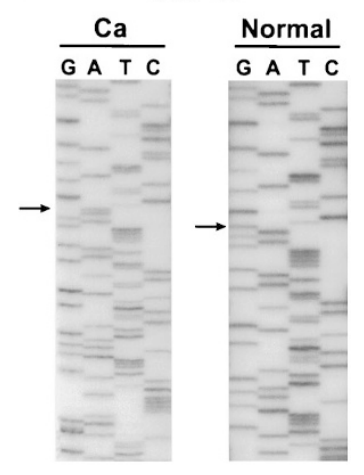

FIGURE 2. A, allelic loss of chromosome $5 q$ in adenocarcinoma (T) as compared with control nonneoplastic esophageal mucosa $(\mathrm{N})$. Allelic loss (arrow) is evidenced by the absence of one heterozygous band in two microsatellite markers (D5S299 and D5S82). B, a missense mutation (AGT $\rightarrow$ AAT, Ser to Asn) of APC gene at codon 1398 was detected in the same adenocarcinoma (Ca) shown in panel A, but not in the control normal esophageal squamous mucosa. Arrow indicates the nucleotide change form $\mathrm{G}$ to $\mathrm{A}$.

\section{DISCUSSION}

The Wnt signaling transduction pathway, a homologue of the Wingless (Wg) signaling pathway in Drosophila, plays an important role in mammalian tumorigenesis (36-37). Both APC and $\beta$-catenin are involved in the Wnt signaling transduction pathway (36-37). APC can bind to GSK- $3 \beta$ to control phosphorylation and degradation of $\beta$-catenin (21-24). The $A P C$ gene functions as a gatekeeper and plays an important role in the early stage of colorectal carcinogenesis (37-38). The majority (more than $80 \%$ ) of the sporadic colorectal carcinomas have somatic $A P C$ mutations (39-40), and mutations of $\beta$-catenin are frequently identified in colorectal carcinomas without $A P C$ gene mutation (19, 27-28). In esophageal adenocarcinoma, in contrast to colorectal carcinoma, p53 tumor suppressor gene appears to play an important role in the early stage of carcinogenesis (41-43). Chromosomal allelic loss on $17 \mathrm{p}$ has been detected in the diploid cell populations and precedes the development of aneuploidy and often precedes allelic loss on $5 q$ during the neoplastic progression of Barrett adenocarcinoma (41-43).

In this study, $45.3 \%$ of the esophageal and EGJ adenocarcinomas had $5 q$ allelic loss, but only one tumor with missense mutation at codon 1398 was detected. No DNA polymorphism of $A P C$ gene has been mapped to this codon. The presence of normal DNA sequence in the normal mucosa again supports that this is a missense mutation rather than just a DNA polymorphism. The significance of this missense mutation is not clear. The absence of nonsense mutations of $A P C$ gene in this series might be attributed to the fact that we sequenced only the mutation cluster region of $A P C$ gene (35). 
However, this result is similar to the previously published report that nonsense mutation of $A P C$ gene is identified in only $5.5 \%(1 / 18)$ esophageal adenocarcinoma (30). Therefore, in esophageal adenocarcinoma, unlike colorectal carcinoma, mutations of $A P C$ gene are uncommon in spite of frequent chromosomal $5 q$ allelic loss. The presence of frequent $5 \mathrm{q}$ allelic loss but not $A P C$ gene mutations suggest that other candidate tumor suppressor gene in the chromosome $5 q$ may play an important role in the esophageal carcinogenesis.

$\beta$-catenin is involved in two major functions: cell adhesion and the transmission of the proliferation signal of the Wnt pathway (36). Activation of the $\beta$-catenin gene occurring through mutation in the region of GSK- $3 \beta$ phosphorylation site in exon 3 has been frequently reported in sporadic colorectal carcinomas with microsatellite instability phenotype and hereditary nonpolyposis colorectal cancer $(29,44)$. In addition to colorectal carcinoma, mutations of $\beta$-catenin gene have also been reported in various tumors including hepatoblastoma, hepatocellular carcinoma, Wilms' tumor, endometrial carcinoma, gastric carcinoma, sporadic medulloblastoma, thyroid carcinoma, and prostate cancer (45-54). We found two (2\%) esophageal and EGJ adenocarcinomas with mutations in the $\beta$-catenin gene. Both mutations were missense mutations at codon 37 representing the phosphorylation site for GSK-3 $\beta$. No mutations were identified in dysplastic or nondysplastic Barrett mucosa adjacent to one adenocarcinoma with $\beta$-catenin gene mutation. These findings indicate that mutations in the $\beta$-catenin gene occur in a small subset of esophageal and EGJ adenocarcinoma and occur in the late stages of carcinogenesis. Abnormal expression of $\beta$-catenin/E-cadherin complex, especially reduction of $\beta$-catenin/E-cadherin gene expression using immunohistochemical stains, has been reported in Barrett esophagus and esophageal adenocarcinomas (31-33). The reason for the presence of abnormal $\beta$-catenin/E-cadherin gene expression is not clear and certainly can not be explained by the presence of $\beta$-catenin gene mutations, a condition in which accumulation of $\beta$-catenin protein is expected (25-26).

In conclusion, we have shown that mutations in the $\beta$-catenin gene occur in a small subset of esophageal and GEJ adenocarcinomas. The presence of frequent $5 \mathrm{q}$ allelic loss but absence of nonsense mutations in the $A P C$ gene further supports that other candidate tumor suppressor gene(s) in the long arm of chromosome 5 may be responsible for esophageal and EGJ carcinogenesis.

\section{REFERENCES}

1. Blot WJ. Esophageal cancer trends and risk factors. Semin Oncol 1994;2:403-10.
2. Heitmiller RF, Sharma RR. Comparison of prevalence and resection rates in patients with esophageal squamous cell carcinoma and adenocarcinoma. J Thorac Cardiovasc Surg 1996;112:130-6.

3. Winters C, Spurling TJ, Chobanian SJ, Curtis DJ, Esposito RL, Hacker JF, et al. Barrett's esophagus: a prevalent occult complication of gastroesophageal reflux disease. Gastroenterology 1987;92:118-24.

4. Spechler SJ, Goyal RK. Barrett's esophagus. N Engl J Med 1986;315:362-71.

5. Haggitt RC. Barrett's esophagus, dysplasia, and adenocarcinoma. Hum Pathol 1994;25:982-93.

6. Spechler SJ. Barrett's esophagus. Gastroenterologist 1994;2: 273-84.

7. Hamilton SR, Smith RRL. The relationship between columnar epithelial dysplasia and invasive adenocarcinoma arising in Barrett's esophagus. Am J Clin Pathol 1987;87:301-12.

8. Hameeteman W, Tytgat GNJ, Houthoff HJ, van den Tweel JG. Barrett's esophagus: development of dysplasia and adenocarcinoma. Gastroenterology 1989;96:1249-56.

9. Cameron AJ, Ott BJ, Payne WS. The incidence of adenocarcinoma in columnar-lined Barrett's esophagus. N Engl J Med 1985;313:857-9.

10. Reid BJ, Blount PL, Rubin CE, Levine DS, Haggitt RC, Rabinovitch PS. Flow-cytometric and histological progression to malignancy in Barrett's esophagus: prospective endoscopic surveillance of a cohort. Gastroenterology 1992;102:1212-9.

11. Wu T-T, Watanabe T, Heitmiller R, Zahrak M, Forastiere AA, Hamilton SR. Genetic alterations in Barrett esophagus and adenocarcinomas of the esophagus and esophagogastric junction region. Am J Pathol 1998;153:287-94.

12. Barrett MT, Galipeau PC, Sanchez CA, Emond MJ, Reid BJ. Determination of the frequency of loss heterozygosity in esophageal adenocarcinoma by cell sorting, whole genomic amplification and microsatellite polymorphisms. Oncogene 1996;12:1873-8.

13. Hammoud ZT, Kaleem Z, Cooper JD, Sundaresan RS, Patterson GA, Goodfellow PJ. Allelotype analysis of esophageal adenocarcinomas: evidence for the involvement of sequence on the long arm of chromosome 4. Cancer Res 1996;56: 4499-502.

14. Huang Y, Boynton RF, Blount PL, Silverstein RJ, Yin J, Tong $\mathrm{Y}$, et al. Loss of heterozygosity involves multiple tumor suppressor genes in human esophageal cancers. Cancer Res 1992;52:6525-30.

15. Meltzer SJ. The molecular biology of esophageal carcinoma. Recent Results Cancer Res 1996;142:1-8.

16. Montesano R, Hollsein M, Hainaul P. Genetic alterations in esophageal cancer and their relevance to etiology and pathogenesis: a review. Int J Cancer 1996;69:225-35.

17. Barrett MT, Sanchez CA, Galipeau PC, Neshat K, Emond M, Reid BJ. Allelic loss of 9p21 and mutation of the CDKN2/ p16 gene develop as early lesions during neoplastic progression in Barrett's esophagus. Oncogene 1996;13:1867-73.

18. Barrett MT, Schutte M, Kern SE, Reid BJ. Allelic loss and mutational analysis of the DPC4 gene in esophageal adenocarcinoma. Cancer Res 1996;56:4351-3.

19. Morin PJ, Sparks AB, Korinek V, Barker N, Clevers H, Vogelstein $\mathrm{B}$, et al. Activation of $\beta$-catenin-Tcf-signaling in colon cancer by mutations in $\beta$-catenin of APC pathway. Science 1997;275:1787-90.

20. Korinek V, Barker N, Morin PJ, Wichen DV, Weger RD, Kinzler KW, et al. Constitutive transcriptional activation by $\beta$-catenin-Tcf complex in APC-/- colon carcinoma. Science 1993;275:1784-7.

21. Su LK, Vogelstein B, Kinzler KW. Association of the APC tumor suppressor protein with catenins. Science 1993;262: $1734-7$. 
22. Rubinfeld B, Souza B, Albert I, Muller O, Chamberlain SH, Masiarz FR, et al. Association of the APC gene product with $\beta$-catenin. Science 1993;262:1731-4.

23. Orford K, Crockett C, Jensen JP, Weisman AM, Byers SW. Serine phosphorylation-regulated ubiquitination and degradation of $\beta$-catenin. J Biol Chem 1997;272:24735-8.

24. Aberle H, Bauer A, Stappert J, Kispert A, Kemler R. $\beta$-Catenin is a target for the ubiquitin-proteasome pathway. EMBO J 1997; 16:3797-804.

25. Rubinfeld B, Albert I, Porfiri E, Fiol C, Munemitsu S, Polakis P. Binding of GSK3- $\beta$ to the APC- $\beta$-catenin complex and regulation of complex assembly. Science 1996;272:1023-5.

26. Munemitsu S, Albert I, Souza B, Rubinfeld B, Polakis P. Regulation of intracellular $\beta$-catenin levels by the adenomatous polyposis coli (APC) tumor suppressor protein. Proc Natl Acad Sci U S A 1995;92:3046-50.

27. Sparks AB, Morin PJ, Vogelstein B, Kinzler KW. Mutational analysis of the APC/ $\beta$-catenin/Tcf pathway in colorectal cancer. Cancer Res 1998;58:1130-4.

28. Iwao K, Nakamori S, Kameyama M, Imaoka S, Kinoshita M, Fukui T, et al. Activation of the $\beta$-catenin gene by interstitial deletions involving exon 3 in primary colorectal carcinomas without adenomatous polyposis coli mutations. Cancer Res 1998;58:1021-6.

29. Miyaki M, Iijima T, Kimura J, Yasuno M, Mori T, Hayashi Y, et al. Frequent mutation of $\beta$-catenin and APC genes in primary colorectal tumors from patients with hereditary nonpolyposis colorectal cancer. Cancer Res 1999;59:4506-9.

30. Powell SM, Papadopoulos N, Kinzler KW, Smolinski KN, Meltzer SJ. APC gene mutations in the mutation cluster region are rare in esophageal cancers. Gastroenterology 1994;107:1759-63.

31. Krishnadath KK, Tilanus HW, Van Blankenstein M, Hop WCJ, Kremers ED, Dinjens WNM, et al. Reduced expression of the cadherin-catenin complex in oesophageal adenocarcinoma correlates with poor prognosis. Am J Pathol 1998; 153:287-94.

32. Bailey T, Biddlestone L, Shepherd N, Barr H, Warner P, Jankowski J. Altered cadherin and catenin complexes in the Barrett's esophagus-dysplasia-adenocarcinoma sequence. Am J Pathol 1998;152:135-44.

33. Washington K, Chiappori A, Hamilton K, Shyr Y, Blanke C, Johnson D, et al. Expression of $\beta$-catenin, $\alpha$-catenin, and E-cadherin in Barrett's esophagus and esophageal adenocarcinomas. Mod Pathol 1998;11:805-13.

34. Moskaluk CA, Kern SE. Microdissection and polymerase chain reaction amplification of genomic DNA from histological tissue sections. Am J Pathol 1997;150:1547-52.

35. Yashima K, Nakamori S, Murakami Y, Yamaguchi A, Hayashi $\mathrm{K}$, Ishikawa $\mathrm{O}$, et al. Mutations of the adenomatous polyposis coli gene in the mutation cluster region: comparison of human pancreatic and colorectal cancers. Int J Cancer 1994; 59:43-7.

36. Gumbiner BM. Signaling transduction of $\beta$-catenin. Curr Opin Cell Biol 1995;7:634-70.

37. Kinzler KW, Vogelstein B. Lessons from hereditary colon cancer. Cell 1996;87:159-70.
38. Fearon ER, Vogelstein B. A genetic model for colorectal tumorigenesis. Cell 1990;61:759-67.

39. Miyoshi Y, Nagase H, Ando H, Horii A, Ichii S, Nakatsuru S, et al. Somatic mutations of the APC gene in colorectal tumors: mutation cluster region in the APC gene. Hum Mol Genet 1992;1:229-33.

40. Powell SM, Zili N, Beazer-Barclay Y, Bryan TM, Hamilton SR, Thibodeau SN, et al. APC mutations occur early during colorectal tumorigenesis. Nature 1992;359:235-7.

41. Blount PL, Meltzer SJ, Yin J, Huang Y, Krasna MJ, Reid BJ. Clonal ordering of $17 p$ and $5 q$ allelic loses in Barrett dysplasia and adenocarcinoma. Proc Natl Acad Sci U S A 1993;90: 3221-5.

42. Blount PL, Galipeu PC, Sanchez CA, Neshat K, Levine DS, Yin $\mathrm{J}$, et al. 17p allelic losses in diploid cells of patients with Barrett's esophagus who develop aneuploidy. Cancer Res 1994;54:2292-5.

43. Barrett MT, Sanchez CA, Prevo LJ, Wong DJ, Galipeau PC, Paulson TG, et al. Evolution of neoplastic cell lineages in Barrett oesophagus. Nat Genet 1999;22:106-9.

44. Mirabelli-Primdahl L, Gryfe R, Kim H, Millar A, Luceri C, Dale $\mathrm{D}$, et al. $\beta$-catenin mutations are specific for colorectal carcinomas with microsatellite instability but occur in endometrial carcinomas irrespective of mutator pathway. Cancer Res 1999;59:3346-51.

45. Oda H, Imai Y, Makatsuru Y, Hata J, Ishikawa T. Somatic mutations of the APC gene in sporadic hepatoblastomas. Cancer Res 1996;56:3320-3.

46. Koch A, Denkhaus D, Albrecht S, Leuschner I, von Schwinitz D, Pietsch T. Childhood hepatoblastomas frequently carry a mutated degradation targeting box of the $\beta$-catenin gene. Cancer Res 1999;59:269-73.

47. Miyoshi Y, Iwao K, Nagasawa Y, Aihara T, Sasaki Y, Imaoka S, et al. Activation of the $\beta$-catenin gene in primary hepatocellular carcinomas by somatic alterations involving exon 3 . Cancer Res 1998;58:2424-7.

48. Koesters R, Ridder R, Kopp-Schneider A, Betts D, Adams V, Niggli F, et al. Mutational activation of the $\beta$-catenin protooncogene is a common event in the development of Wilms' tumors. Cancer Res 1999;59:3880-2.

49. Fukuchi T, Sakamoto M, Tsuda H, Maruyama K, Nozawa S, Hirohashi S. $\beta$-catenin mutation in carcinoma of the uterine endometrium. Cancer Res 1998;58:3526-8.

50. Palacios J, Gamallo C. Mutations in the $\beta$-catenin gene in endometrioid ovarian carcinomas. Cancer Res 1998;58:1344-7.

51. Park WS, Oh RR, Park JY, Lee SH, Shin MS, Kim YS, et al. Frequent somatic mutations of the $\beta$-catenin gene in intestinal-type gastric cancer. Cancer Res 1999;59:4257-60.

52. Zurawel RH, Chiappa SA, Allen C, Raffel C. Sporadic medulloblastomas contain oncogenic $\beta$-catenin mutations. Cancer Res 1998;58:896-9.

53. Garcia-Rostan G, Tallini G, Herrero A, D'Aquila TG, Carcangiu ML, Rimm DL. Frequent mutation and nuclear localization of $\beta$-catenin in anaplastic thyroid carcinoma. Cancer Res 1999;59:1811-5.

54. Voeller HJ, Truica C, Gelmann EP. $\beta$-catenin mutations in human prostate cancer. Cancer Res 1998;58:2520-3. 